\title{
INFERTILITY IN MICE CAUSED BY FASTING AT ABOUT THE TIME OF MATING
}

\author{
III. PATHOGENESIS
}

\author{
T. J. McCLURE \\ Department of Veterinary Medicine, The University of Sydney, N.S.W.
}

(Received 15th June 1966, revised 10th November 1966)

\begin{abstract}
Summary. Experiments designed to find the pathogenesis of the infertility caused by fasting mice for 18 to $48 \mathrm{hr}$ at about the time of mating showed that: (a) within $4 \mathrm{hr}$ of removal of all food the blood-glucose level fell to about half, and that this fall was delayed for about $24 \mathrm{hr}$ by adding glucose to the drinking water; (b) protamine zinc insulin reduced both blood-glucose level and littering rate; (c) 2-deoxy-D-glucose (2DG) inhibited ovulation and caused the death of tubal ova; (d) fasting, insulin and 2DG appeared to cause similar effects upon the fertility; and (e) the expected infertility of fasted mice was prevented by the administration of human chorionic gonadotrophin and progesterone at the appropriate times.

The evidence suggested that the primary biochemical disturbance was hypoglycaemia and that this inhibited adenohypophysial gonadotrophic function.
\end{abstract}

\section{INTRODUCTION}

The reproductive cycle of female mice appears to be sensitive to the effects of fasting for 18 to $48 \mathrm{hr}$ from up to 2 days before mating to 6 to 8 days after mating (McClure, 1959, 1966, 1967). The lesions produced seem to depend upon the stage of the cycle at which the mice are exposed to fasting, and range from failure of ovulation when fasting occurs before mating to death and resorption of the implanted embryos when fasting occurs during implantation. At intermediate times reproductive failures include failure of cleavage, death of ova, morulae and blastocysts and failure of implantation. Thirty-six to 48-hr fasting also causes anoestrum in a high proportion of females. The primary cause of the infertility appears to be an acute energy deficiency.

Possibly the fasting causes hypoglycaemia which inhibits adenohypophysial gonadotrophic function and consequently failure of ovulation or development of tubal ova. Pituitary luteotrophic failure has been shown to occur in the olfactory block to pregnancy (Bruce \& Parkes, 1960) and also appears to be involved in implantation failure in mice and rats induced by 2 to 3 days fasting at a later period (McClure, 1959, 1961; Chambon, 1960). Earlier workers 
(Marrian \& Parkes, 1929; Werner, 1939; Pomerantz \& Mulinos, 1939; Rinaldini, 1949) have shown that longer periods of inanition cause pituitary gonadotrophic failure and anoestrum. The results of current experiments did not suggest that temporary hypersecretion of corticosterone or hypothyroidism were involved in the pathogenesis.

This paper reports the results of experiments designed to find the intermediate steps between the temporary deprivation of food at about the time of mating and the ovulatory failure, death of the ova or failure of implantation, with particular attention to hypoglycaemia and adenohypophysial gonadotrophic inhibition.

\section{EXPERIMENTAL METHODS AND RESULTS}

The general materials and methods have been described previously (McClure, 1966, 1967).

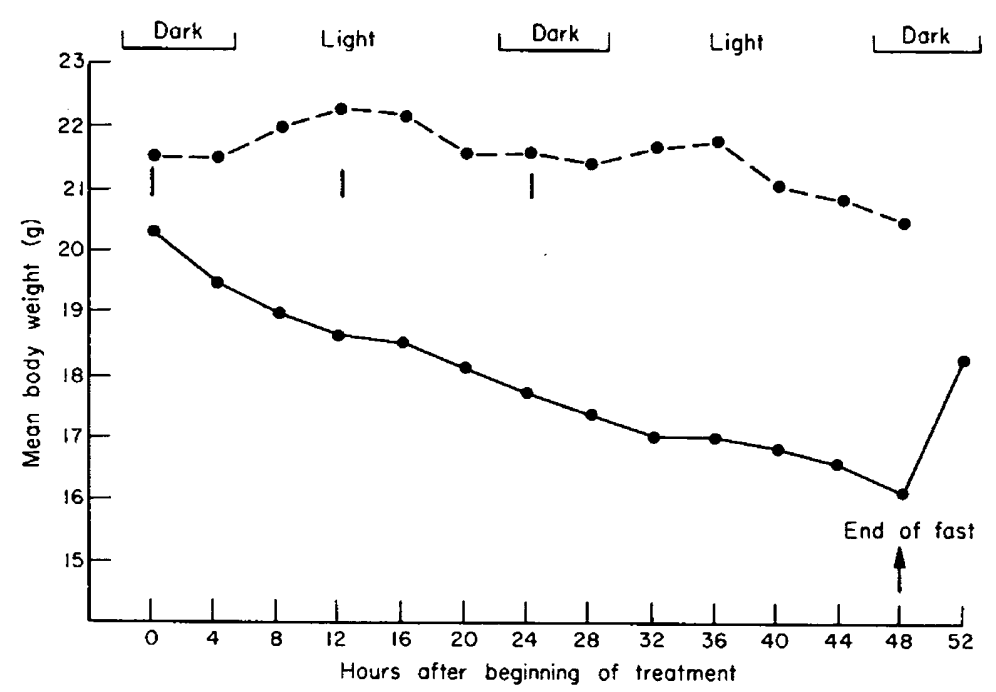

TEXT-FIC. 1. Mean body weight changes of fasted (-) and insulin-treated (- . - ) mice.

Body-zeeight changes during fasting (Text-fig. 1)

Ten female mice were weighed individually at 4-hourly intervals for the first $48 \mathrm{hr}$ after all their food, but not water, had been removed, and again $4 \mathrm{hr}$ after food was replaced.

Blood-glucose levels during fasting (Text-fig. 2)

Seventy-five unmated female mice were divided into five groups and fasted for $48 \mathrm{hr}$. Every $4 \mathrm{hr}$ during fasting and 4 and $24 \mathrm{hr}$ after the end of fasting one (fresh) mouse was taken from each group and quickly bled from the cavernous sinus (as described by Lapeyrac (1963), but without anaesthesia) and the glucose level in the blood sample was determined by the glucose oxidase method of Huggett \& Nixon (1957). 
The mean blood-glucose levels of the fasted mice at Hour 0 was 136.9 , S.D. $=13 \cdot 5, \mathcal{N}=5$, at Hour 4 to 20 inclusive 59.6, S.D. $=13 \cdot 5, \mathcal{N}=24$, and at Hour 4 to 48 inclusive 58.2, S.D. $=19 \cdot 9, \mathcal{N}=59$. The differences between the mean levels at Hour 0 and Hour 4 to 20, and Hour 0 and Hour 4 to 48 are both significant $(P<0.001)$.

Blood-glucose levels of mice fed only glucose solution (Text-fig. 2)

All the normal food and drinking water of twenty-six female mice in two groups of thirteen was replaced for $48 \mathrm{hr}$ by a $50 \% \mathrm{w} / \mathrm{v}$ solution of D-glucose. Every $4 \mathrm{hr}$ one (fresh) mouse from each group was bled and the blood-glucose level determined.

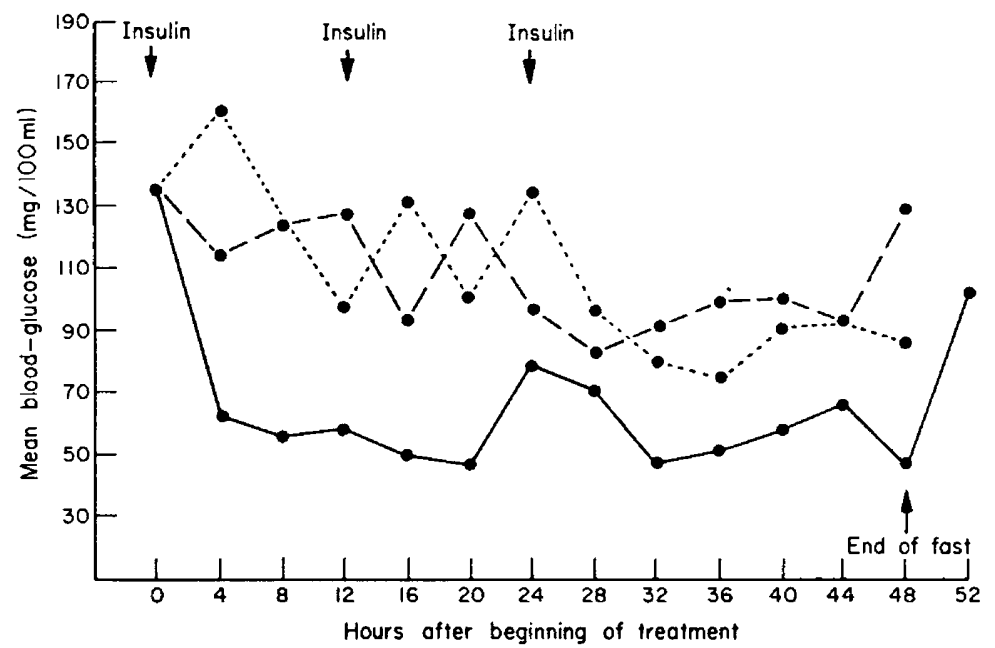

TExT-FIG. 2. Mean blood-glucose levels of fasted and insulin-treated mice. _- Fasted; -.. -, insulin; $\cdots$, , fasted + glucose.

The mean blood-glucose level of mice given glucose solution only at Hour 0 was $136 \cdot 9$, S.D. $=13 \cdot 5, \mathcal{N}=5$, and the mean at Hour 4 to 28 was $121 \cdot 3$, S.D. $=24 \cdot 1, \mathcal{N}=12$. This difference is not significant $(0 \cdot 50>P>0 \cdot 10)$. Some reduction occurred after $28 \mathrm{hr}$.

Littering (No. littering/No. mated) rates after insulin treatment (Table 1)

Female mice allowed access to unlimited amounts of food were given three subcutaneous injections each of $0.15 \mathrm{ml}$ containing $0,0.06,0.09,0.18$ or 0.27 units of protamine zinc insulin in $0.15 \mathrm{ml}$ distilled water at 12 -hr intervals at $08.00,20.00$ and 08.00 hours, the last injection being given at times which ranged from 4 days before to 5 days after mating. Control mice were given injections of $0.15 \mathrm{ml}$ water at comparable times. After mating the mice were allowed to complete the normal terms of gestation and the proportions of mated mice which littered were determined.

Insulin appeared to have depressed the littering rates of the mice. The mice appeared particularly sensitive to the insulin when it was given: (a) in three doses of 0.06 and 0.09 units ending 0 to 2 days before mating; (b) in three doses 


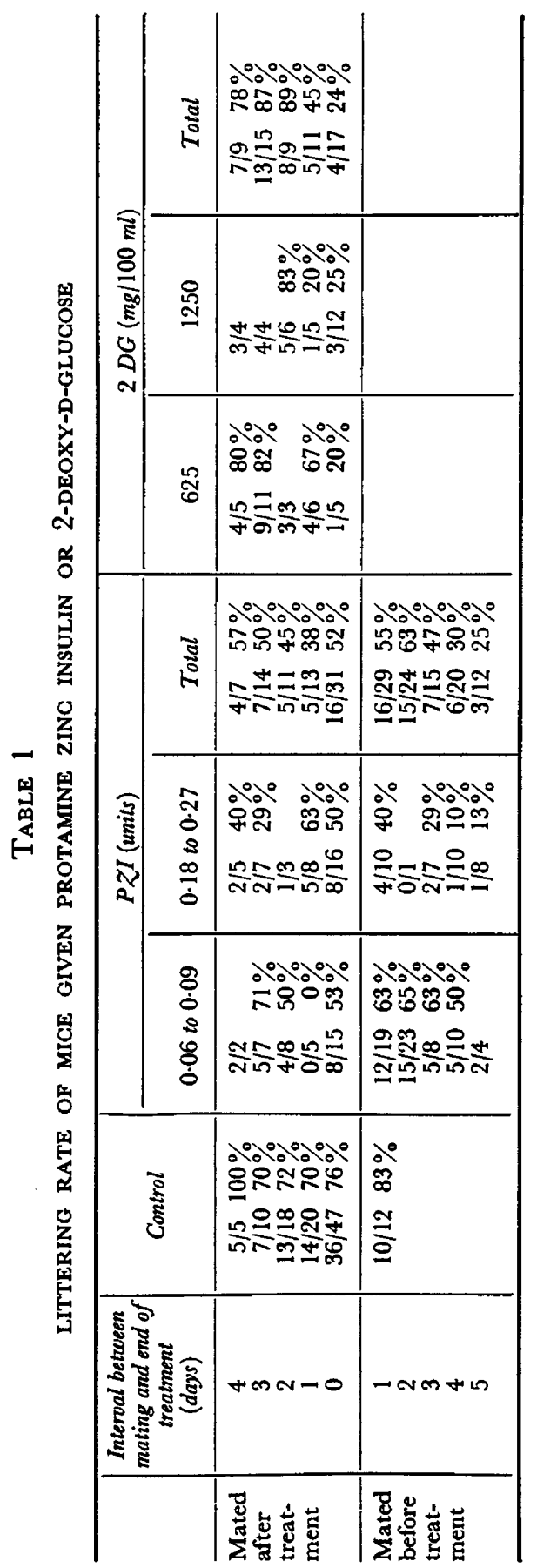


Infertility caused by fasting. III

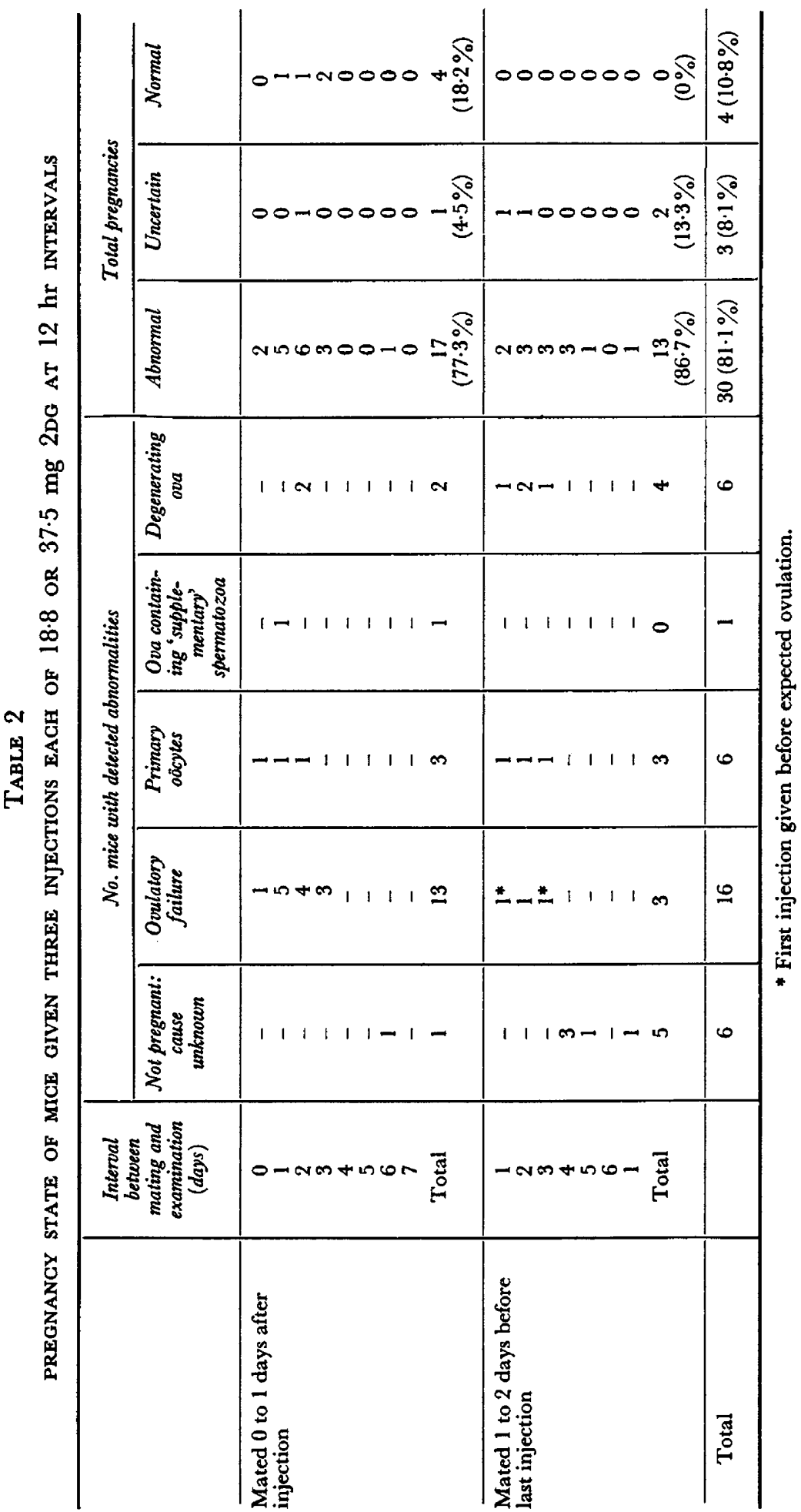


of 0.18 and 0.27 units ending 2 to 4 days before mating; and (c) at both dose rates close to the time of implantation. In all three cases the differences from the control rates are significant $(P<0.001)$. The 0.27 unit dose caused the death of five out of thirty-eight treated mice apparently from hypoglycaemia and relatively few were mated within the 5-day period after treatment.

\section{Blood-glucose levels of insulin-treated mice (Text-fig. 2)}

Forty-five mice in three groups of fifteen were given three injections each of 0.09 units (the lowest effective dose) of protamine zinc insulin at 12-hr intervals. Every $4 \mathrm{hr}$ one (fresh) mouse from each group was sampled and the bloodglucose level determined. The mice were allowed access to unlimited food and water at all times.

During the period Hour 4 to 20 the mean blood-glucose level of the treated mice was $117 \cdot 8$, S.D. $=17 \cdot 35, \mathcal{N}=13$. Compared with the control value at Hour 0 this reduction in glucose level is significant $(0 \cdot 05>P>0 \cdot 02)$. The fall continued over the period Hour 24 to 44, i.e. after the last injection, to a mean of $95 \cdot 5$, S.D. $=25 \cdot 3, \mathcal{N}=17$. This is significantly lower than the mean at Hour $0(P<0 \cdot 001)$.

\section{Body-weight changes after insulin treatment (Text-fig. 1)}

Ten fully fed mice, given three injections of 0.09 units of protamine zinc insulin at 12-hr intervals, were weighed every $4 \mathrm{hr}$. The treatment appears to have had no effect upon body-weight for at least the first $40 \mathrm{hr}$.

\section{Littering rates after 2-deoxy-D-glucose treatment (Table 1)}

Female mice fed ad libitum were given, instead of their drinking water, a solution containing 625 or $1250 \mathrm{mg}$ of the glucose antimetabolite 2-deoxy-Dglucose (2DG) (Hochster, 1963) /100 ml which was given for 24, 36 or $48 \mathrm{hr}$, ending just before the third period of darkness after placing males in subcages within the cages of females. The males which had had access to tap water without the 2DG were released and the test solution was replaced with tap water at the beginning of the third period of darkness. The daily consumption of the 2DG solution was in the order of 4 to $6 \mathrm{ml} /$ mouse. Dehydration controls, i.e. mice offered food, but not water, for 24 to $48 \mathrm{hr}$ were included to check the possibility that failure to drink sufficient water may have influenced the results.

The difference in the littering rate of mice mated 0 and 1 day after being given the stronger solution of $2 \mathrm{DG}$ is, at $4 / 17$, significantly different from the $10 / 15$ for the dehydrated control mice mated on the same days $(0.02>P>0.01)$.

\section{Lesions caused by 2DG (Table 2)}

Female mice allowed access to unlimited amounts of food were given three injections each of 18.8 or $37.5 \mathrm{mg}$ of $2 \mathrm{DG}$ at 12 -hr intervals. The last injection was given at the beginning of the third period of darkness after introducing the males into the cages of females. The females mated 0 or I day after the last injection were killed and examined as described previously (McGlure, 1967) to determine the state of pregnancy. Additional mice were similarly treated with 2DG 0 to 2 days after mating. The data from the control mice were reported 
previously and the lesions and abnormalities found were similar to those described in the fasted mice (McClure, 1967).

The protective effect of human chorionic gonadotrophin (Table 3)

At 22.30 hours on the day before the third period of darkness after the introduction of the males and $12 \frac{1}{2} \mathrm{hr}$ after the commencement of a 30 -hr fast, female mice were each given a s.c. injection of 3 i.u. of human chorionic gonadotrophin ( $\mathrm{HCG}$ ) in $0.15 \mathrm{ml}$ of water. The injection was given $7 \frac{1}{2} \mathrm{hr}$ before the period of darkness and about 10 to $12 \mathrm{hr}$ before the expected time of ovulation in the majority of the mice. The injected mice, 30-hr fasted control, and unfasted control mice which were mated during the third and fourth periods of darkness, were killed and their condition determined 7 days after mating.

The protective effect of progesterone (Table 3 )

Mice, fasted for $30 \mathrm{hr}$ ending between 4 days before mating and 2 days after mating, were given $0.2 \mathrm{mg}$ progesterone in $0.15 \mathrm{ml}$ peanut oil subcutaneously

TABLE 3

PREGNANCY STATE OF FASTED MICE GIVEN HCG OR PROGESTERONE

\begin{tabular}{|c|c|c|c|c|c|}
\hline & \multirow{2}{*}{$\begin{array}{l}\text { Interval between } \\
\text { mating and end } \\
\text { of fasting } \\
(\text { days })\end{array}$} & \multicolumn{2}{|c|}{ Control } & \multicolumn{2}{|c|}{ Fasted+ } \\
\hline & & Not fasted & Fasted & $H C G$ & Progesterone \\
\hline \multirow[t]{2}{*}{$\begin{array}{l}\text { Mated after } \\
\text { fasting }\end{array}$} & $\begin{array}{l}1 \\
0\end{array}$ & $\begin{array}{l}1 / 1 \\
8 / 9\end{array}$ & $\begin{array}{l}2 / 15 \\
3 / 13\end{array}$ & $\begin{array}{l}0 / 0 \\
8 / 9\end{array}$ & $\begin{array}{l}1 / 5 \\
1 / 3\end{array}$ \\
\hline & Total & $\begin{array}{c}9 / 10 \quad 90 \% \\
\text { (a) }\end{array}$ & $5 / 28$ (b) $18 \%$ & $8 / 9 \underset{\text { (c) }}{89 \%}$ & $2 / 8$ (d) $25 \%$ \\
\hline \multirow[t]{2}{*}{$\begin{array}{l}\text { Mated before } \\
\text { fasting }\end{array}$} & $\begin{array}{l}1 \\
2\end{array}$ & & $\begin{array}{l}2 / 10 \\
2 / 4\end{array}$ & & $\begin{array}{c}10 / 14 \\
4 / 4\end{array}$ \\
\hline & Total & & $4 / 14{ }_{(\mathrm{e})}^{29 \%}$ & & $\begin{array}{c}14 / 18 \\
\text { (f) }\end{array} 78 \%$ \\
\hline & & $\begin{array}{l}\text { tsus c } P>0 \cdot 0 \\
\text { sus d } P- \\
\text { sus f } P=0\end{array}$ & $\begin{array}{r}\mathrm{NS} \\
\mathrm{NS} \\
0.001\end{array}$ & & \\
\hline
\end{tabular}

once daily from the day of mating until they were killed and the uterus examined 6 days later when the results of treatment should have been apparent. Control mice were injected with $0.15 \mathrm{ml}$ peanut oil.

Survival and development of ova after early ovariectomy

Ether-anaesthetized mice were ovariectomized through bilateral flank incisions about $17 \mathrm{hr}$ after finding the copulation plugs (probably 18 to $24 \mathrm{hr}$ after ovulation). The mice were killed 24 or $48 \mathrm{hr}$ later and the ova examined as described in Part II (McClure, 1967). Control mice were laparotomized but not ovariectomized.

Normal developing ova were found in twelve out of sixteen $(75 \%)$ of the laparotomized control mice, but none was found in the sixteen ovariectomized mice. Fragmenting ova were recovered from ten $(63 \%)$ and no ova were recovered from the remaining six. 


\section{DISCUSSION}

Fasting caused a progressive fall in body-weight and a rapid reduction in blood-glucose within $4 \mathrm{hr}$ to a static level about half that of normal. Glucose administered in the drinking water during the period the normal food was withheld enabled the mice to maintain their blood-glucose level for $24 \mathrm{hr}$, leaving a period of only $6 \mathrm{hr}$ of hypoglycaemia at the end of a 30-hr period of fasting; and, as mice given glucose in their drinking water during a 30-hr period without their normal food had normal littering rates (McClure, 1966), it would appear that the acute inanition may have exerted its effect by means of hypoglycaemia and that this was the primary biochemical failure.

Support for this hypothesis was provided by the experiments in which the glucose metabolism of fully fed mice was inhibited by insulin and 2DG, by the time relationships of the treatments to maximal depressant effect on littering rates and by the magnitude of the blood-glucose changes produced. Three

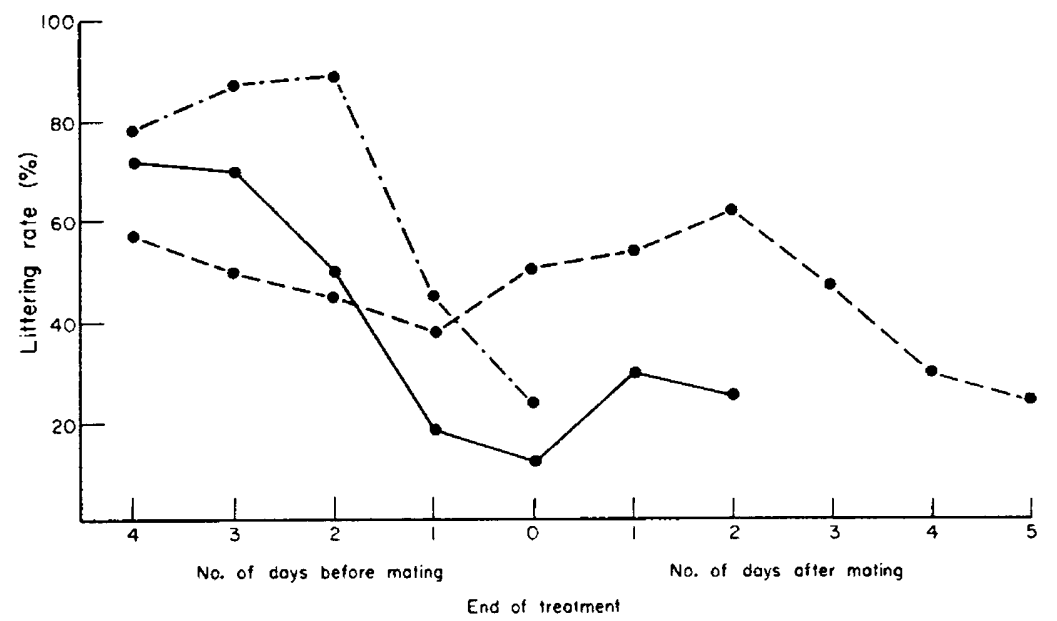

TEXT-FIG. 3. Effect of fasting ( - ), insulin (- .-) and 2DG (- . . -) given at various times before and after mating on littering rates.

injections of 0.09 units at 12 -hr intervals caused in the mean blood-glucose levels a significant reduction of $19.1 \mathrm{mg} / 100 \mathrm{ml}$ or $13.9 \%$ during the first $20 \mathrm{hr}$ after the first injection, and during the succeeding $24 \mathrm{hr}$ a greater fall totalling $41.4 \mathrm{mg} / 100 \mathrm{ml}$ or $30.1 \%$ below the pre-treatment level. Fasting for 30 to $48 \mathrm{hr}$ was most effective when it ended on the day of mating (McClure, 1966) but insulin treatment was most effective (particularly the 0.09 unit dose) when it ended 1 day earlier (Table 1, Text-fig. 3). Fasting caused an immediate (less than $4 \mathrm{hr}$ ) fall in the blood glucose level but the insulin caused its greatest depression $24 \mathrm{hr}$ later (Text-fig. 2). If hypoglycaemia was in fact the primary change, a fall in the blood-glucose level from a mean in the order of 140 to 120 $\mathrm{mg} / 100 \mathrm{ml}$ appears to have had little effect, but the fall to below $100 \mathrm{mg} / 100 \mathrm{ml}$ would seem to have depressed the fertility.

Insulin-induced hypoglycaemia causing a fall in the blood glucose from the normal of 80 to $100 \mathrm{mg} / 100 \mathrm{ml}$ to 50 to $70 \mathrm{mg} / 100 \mathrm{ml}(30$ to $37.5 \%$ ) is sufficient 
to cause changes in sensation and electrical conductivity (McIlwain, 1959). Such a fall is less than that occurring in the fasted mice and similar to that in the mice given 0.09 units of protamine zinc insulin. Similarly Pushkarev (1964) found, in cats with insulin-induced hypoglycaemia (blood-sugar level falling from $150 \mathrm{mg} / 100 \mathrm{ml}$ to 60 to $75 \mathrm{mg} / 100 \mathrm{ml}$ ), the function of all ganglionic structures and pre-synaptic endings was disturbed. It appears possible that the hypoglycaemia could have disturbed hypothalamic function.

The littering rates of mice treated with 2DG appears to have been depressed to a similar degree and with similar time relationships and also produced similar lesions in the ova and ovaries as did fasting (Tables 1 and 2, Text-fig. 3). By being converted to 2-DG-6-phosphate, which is not a substrate for phosphohexose-isomerase or glucose-6-phosphate dehydrogenase enzymatic action (Sols \& Crane, 1954; Hochster, 1963), 2DG would inhibit both the glycolytic and direct oxidative glucose metabolic pathways.

The means by which hypoglycaemia could have produced ovulatory failure, death of tubal ova, failure of implantation and death of implanted embryos is also of importance.

Most of the evidence produced indicates that pituitary gonadotrophic failure is the immediate cause of the lesions produced. The ovaries of the mice fasted for $30 \mathrm{hr}$ before mating resembled, histologically, those described by Chester Jones \& Ball (1962) in hypophysectomized mice in which there are many medium-sized follicles but no corpora lutea (McClure, 1967). Those mice given 2DG before mating contained large unruptured follicles and resembled Chester Jones \& Ball's (1962) hypophysectomized mice which had been injected with FSH but not LH. These considerations, together with: (a) the failure to recover ova from many of the mice fasted before mating, and (b) the normal fertility in mice fasted before mating, but injected with human chorionic gonadotrophin 10 to $12 \mathrm{hr}$ before the expected ovulation, at a time when there is normally a surge in release of LH from the adenohypophysis (Everett, Sawyer \& Markee, 1949; Everett \& Sawyer, 1950; Edwards \& Gates, 1959), suggest that the anterior pituitary gland failed to release sufficient LH and possibly also FSH to cause maturation of the ova and ovulation.

In the case of mice fasted after mating neither ovulatory failure nor the viability of the ova when shed is in doubt. The death of the tubal ova or free uterine blastocysts, the main effects detected, must have been the results of an unfavourable environment. The corpora lutea of about two-thirds of the mice containing degenerating ova were non-hyperaemic indicating a failure of release of luteotrophic hormone and failure of activation of the corpora lutea (Browning, 1962) to produce progesterone. If this failure of the pituitary to produce or release sufficient LTH to convert the corpus luteum of ovulation into a corpus luteum of pregnancy (Eckstein, 1962; Browning, 1962) and so cause a progesterone deficiency, is responsible for the death of the tubal ova, then it is reasonable to expect that the supplementation with progesterone of the mice fasted after mating would raise the fertility to normal. Progesterone had this effect (Table 3). Also ovariectomy was succeeded by fragmentation of tubal ova, although somewhat conflicting evidence has been reported in the literature.

In 1955, Harris and, in 1962, Chester Jones \& Ball referred to the unresolved 
problem of why, in inanition, gonadotrophins are elaborated but not released. The results of the experiments reported in this present paper, suggest that the hypoglycaemia inhibits the production of $\mathbf{L H}$ and FSH releasing factors by the hypothalamus at the same time and possibly by the same method as it depresses other nervous activity. Although LTH release is possibly similarly affected the mechanism is not so clear because of the normal inhibiting control exerted by the hypothalamus in pituitary release of LTH (Meites, Nicoll \& Talwalker, 1963; Grosvenor, McCann \& Nallar, 1965).

Some of the mice fasted for $30 \mathrm{hr}$ ending 0 to 2 days before mating did ovulate but the ova of at least twelve out of twenty-six of these died before implantation at a time when the mice had been re-fed and the blood-glucose levels would have returned to normal (Text-fig. 2). There are three possible reasons for degeneration of these ova: the ova could have been non-viable when shed, the tubal medium could have been unfavourable for their development or they had not been fertilized. In view of the protective effect provided by progesterone in heat-stressed (Macfarlane, Pennycuik \& Thrift, 1957), pyridoxine-deficient (Nelson, Lyons \& Evans, 1951) and multiple-nutrient-deficient rats (Kendall \& Hays, 1960), some protection of the fertility of mice fasted before mating would be expected when progesterone was given after mating if an unfavourable tubal medium was responsible for their death. Although the numbers in this experiment are too small to enable valid conclusions to be drawn, the failure of progesterone to afford protection (Table 3) does suggest that, at the time of ovulation, the ova may have been non-viable.

The reasons for the failure of development of the tubal ova of mice fasted after mating may not be simply the result of luteotrophic failure and progesterone insufficiency. Whitten (1956, 1957) and Brinster (1963, 1965a, b) have shown that development of 2-cell and older mouse ova requires the presence of simple carbohydrates in the medium and that, while the 8-cell ovum is able to utilize glucose, 2-cell ova are able to utilize only lactate, pyruvate, oxaloacetate and phospho-enol pyruvate, i.e. the terminal products of the Embden-Meyerhof glycolytic pathway and the tricarboxylic acid cycles, and substances which are likely to be in short supply in mice affected by fasting, insulin-induced hypoglycaemia or 2DG poisoning. Unfortunately insufficient is known about the concentration of these essential metabolites in the tubal and uterine fluids of the mouse, although in the rabbit it is known that lactate is the major simple carbohydrate present in the tubal fluids (Hamner \& Williams, 1965).

\section{ACKNOWLEDGMENTS}

Acknowledgment is made to Miss A. E. Dowell for technical assistance and to the University of Sydney for a research grant for financial assistance.

\section{REFERENCES}

BRINSter, R. L. (1963) A method for in vitro cultivation of mouse ova from two-cell to blastocyst. Expl Cell Res. 32, 205.

BRINSTER, R. L. (1965a) Studies on the development of mouse embryos in vitro. I. The effect of osmolarity and hydrogen ion concentration. F. exp. Zool. 158, 49. 
Brinster, R. L. (1965b) Studies on the development of mouse embryos in vitro. II. The effect of energy source. f. exp. Zool. 158, 59 .

Browning, H. C. (1962) The production of functional corpora lutea by purified gonadotrophins. Am. Zool. 2, 396.

BrucE, H. M. \& Parkes, A. S. (1960) Hormonal factors in exteroceptive block to pregnancy in mice. 7. Endocr. 20, xxix.

Ghambon, Y. (1960) Deficit alimentaire et ovoimplantation. Soc. belge Gynec. 30, 557.

Ghester Jones, I. \& Ball, J. N. (1962) Ovarian-pituitary relationships. In: The Ovary, Ed. S. Zuckerman. Academic Press, New York.

Eckstein, P. (1962) Ovarian physiology in the non-pregnant female. In: The Ovary. Ed. S. Zuckerman. Academic Press, New York.

Edwards, R. G. \& Gates, A. H. (1959) Timing of the stages of the maturation divisions, ovulation, fertilisation and the first cleavage of eggs of adult mice treated with gonadotrophins. F. Endocr. 18, 292.

EvERETT, J. W. \& SAWYER, C. H. (1950) A 24-hour periodicity in the 'LH release apparatus' of female rats disclosed by barbiturate sedation. Endocrinology, 47, 198.

Everett, J. W., Sawyer, G. H. \& Markee, J. E. (1949) A neurogenic timing factor in control of the ovulatory discharge of luteinizing hormone in the cyclic rat. Endocrinology, 44, 234.

Grosvenor, C. G., MCGANn, S. M. \& NALLAR, R. (1965) Inhibition of nursing-induced fall in pituitary prolactin concentration in lactating rats by injections of acid extracts of bovine hypothalamus. Endocrinology, 76, 883.

Hamner, C. E. \& Williams, W. L. (1965) Composition of rabbit oviduct secretions. Fert. Steril. 16, 170.

HarRIS, G. W. (1955) Neural control of the pituitary gland. Arnold, London.

Hochster, R. M. (1963) Hexose and pentose analogues. Metabolic Inhibitors. Eds. R. M. Hochster and J. H. Quastel. Academic Press, New York.

Huggetr, A. St G. \& Nixon, D. A. (1957) Enzymatic determination of blood glucose. Biochem. 7. 66, $12 \mathrm{p}$.

Kendall, K. A. \& Hays, R. L. (1960) Maintained pregnancy in the rat as associated with progesterone administration and multiple nutrient deficiency. 7 . Nutr. 70, 10.

LAPEYRAc, F. (1963) Revue fr. Etude clin. biol. 8, 195. Cited by Flynn, R. J. (1963) rear Book of Veterinary Medicine, pp. 417-418.

Macfarlane, W. V., Pennycuik, P. R. \& Thrift, E. (1957) Resorption and loss of foetuses in rats living at $35^{\circ}$ C. F. Physiol., Lond. 135, 451.

McClure, T. J. (1959) Temporary nutritional stress and infertility in female mice. 7. Physiol., Lond. $147,221$.

McCuure, T. J. (1961) Pathogenesis of early embryonic mortality caused by fasting pregnant rats and mice for short periods. F. Reprod. Fert. 2, 381.

McClure, T. J. (1966) Infertility in mice caused by acute fasting at about the time of mating. I. Mating behaviour and littering rates. F. Reprod. Fert. 12, 243.

MCCLuRE, T. J. (1967) Infertility in mice caused by acute fasting at about the time of mating. II. Pathological changes. F. Reprod. Fert. 13, 387.

McIlwain, H. (1959) Biochemistry of the central nervous system. Churchill, London.

Marrian, G. F. \& PARkEs, A. S. (1929) The effect of anterior pituitary preparations administered during dietary anoestrus. Proc. R. Soc. B, 105, 248.

Meites, J., Nicoll, C. S. \& TALWALKer, P. K. (1963) The central nervous system and the secretion and release of prolactin. Advances in Neuroendocrinology, pp. 238-277. Ed. A. V. Nalbandov. University of Illinois Press.

Nelson, M. M., Lyons, W. R. \& Evans, H. M. (1951) Maintenance of pregnancy in pyridoxinedeficient rats when injected with estrone and progesterone. Endocrinology, 48, 726.

Pomerantz, L. \& Mulinos, M. G. (1939) Pseudo-hypophysectomy produced by inanition. Am. 7 . Physiol, 126, 601.

Pushkarev, Y. P. (1964) Effect of blood sugar levels on post tetanic potentiation in cat synaptic ganglia. (Translated title). Fiziologicheskii zhurnal SSSR imeni I M Sechenova. 50, 328. Transl. in: Fed. Proc. 24, T340 (1965).

Rinaldini, L. M. (1949) Effect of chronic inanition on the gonadotrophic contents of the pituitary giand. 7. Endocr. 6, 54.

Sols, A. \& GRANE, R. K. (1954) Substrate specificity of brain hexokinase. 7. biol. Chem. 210, 581.

WERNER, S. C. (1939) Failure of gonadotrophic function of the rat hypophysis during chronic inanition. Proc. Soc. exp. Biol. Med. 41, 101.

Whitres, W. K. (1956) Culture of tubal mouse ova. Nature, Lond. 177, 96.

Whirten, W. K. (1957) Culture of tubal ova. Nature, Lond. 179, 1081. 